\title{
Kedudukan Hukum PERMA Nomor 2 Tahun 2012 dalam Perspektif Sistem Peradilan Pidana (Studi di Pengadilan Negeri Kelas I Kupang)
}

\begin{abstract}
Nuriyani T. Ballu
DATA NASKAH:

Masuk: 24 November 2018

Diterima: 24 Desember 2018

Terbit: 31 Desember 2018

KORESPONDEN PENULIS:

Fakultas Hukum, Universitas Nusa

Cendana, Kupang

Email: nuriyaniballu@yahoo.com

ABSTRACT

This study aims to determine the position and the application of criminal penalties in accordance with the Supreme Court Decree Number 2 of 2012 concerning Adjustment of Limitation of Minor Crime and Amount of Fine in the Penal Code from the Perspective of the Criminal Justice System. The nature of research is normative legal research. Data in the form of court decision was take from the Kupang District Court. Study was made against the theft case involving an accused named Yohamir Amtiran Alias Hamir Amtiran which is registered in the mentioned court numbered 205/ Pen.Pid / 2015 / PN.KPG. The accused person has been alleged for having stolen two watches, one with Giotana brand, silvercolored boxy, and another one with SEIKO brand, spherical gold. The theft was committed at night in a house owned by Indriani Listya Purwanti Indri alias Indri located in BSB Housing Complex, Puri Lontar Street, Oebufu Village, Oebobo Subdistrict, in Kupang. The economic value of the stolen properties is approximately Rp 1,500,000.00 (one million and five hundred thousand rupiahs). The accused was tried with the ordinary criminal proceedings and put under detention. It is clear that the judges have not yet implemented the above mentioned Supreme Court Decree.
\end{abstract}

Keywords: Legal Position, Fine, Minor Crime

\section{ABSTRAK}

Penelitian ini dimaksudkan untuk mengetahui kedudukan dan penerapan pidana denda sesuai dengan Peraturan Mahkamah Agung (Perma) Nomor 2 Tahun 2012 tentang Penyesuaian Batasan Tindak Pidana Ringan dan Jumlah Denda dalam KUHP dalam Perspektif Sistem Peradilan Pidana. Jenis penelitian yang dilakukan adalah penelitian normatif. Data berupa putusan pengadilan yang menjadi obyek kajian dalam penelitian ini diperoleh dari Pengadilan Negeri Kelas I Kupang. Kajian dilakukan terhadap perkara tindak pidana pencurian dengan terdakwa bernama Yohamir Amtiran alias Hamir Amtiran yang teregistrasi dengan nomor: 205/Pen.Pid/2015/PN.KPG. Terdakwa didakwa melakukan tindak pidana 
pencurian barang berupa 1 buah jam tangan merk Giotana berwarna silver berbentuk kotak, 1 buah jam tangan merk SEIKO berbentuk bulat berwarna emas pada malam hari disebuah rumah yang tertutup milik saksi korban yang bernama Indriani Listya Purwanti alias Indri di perumahan BSB Jl. Puri Lontar, Kelurahan Oebufu, Kecamatan Oebobo, Kota Kupang. Nilai kerugian yang dialami korban kurang lebih sebesar Rp 1.500.000,00 (satu juta lima ratus ribu rupiah). Terdakwa diadili dengan acara pemeriksaan biasa dan dilakukan penahanan.

Kata Kunci : Kedudukan Hukum, Pidana Denda, Tindak Pidana Ringan

\section{PENDAHULUAN}

Pidana denda sebagai salah satu dari pidana pokok dalam stelsell pidana Indonesia, dan juga merupakan warisan kolonial Belanda dan masih berada di kedudukan sekunder jika dibandingkan dengan pidana pencabutan kemerdekaan. Hal ini tampak pada peraturan dan pengancamannya dalam Kitab Undang-Undang Hukum Pidana yang untuk selanjutnya ditulis sebagai KUHP. Khususnya pada Pasal 69 ayat 1 KUHP yang menetapkan "Perbandingan beratnya pidana pokok yang tidak sejenis ditentukan menurut urutan-urutan dalam Pasal 10". Kenyataan itulah yang menggambarkan perihal rendahnya nilai-nilai dan terbatasnya pidana denda sebagai pidana pokok. Tentu hal-hal inilah yang dimaksudkan untuk membahas faktor-faktor yang menghambat maupun yang menunjung naik dan kuatnya pengaruh pidana denda dalam sistem pidana dan hukum pidana di Indonesia.

Perlu diakui bahwa selama ini KUHP yang dipakai sebagai pedoman dan parameter untuk menentukan kriteria tindak pidana ringan sudah berusia lebih dari 60 tahun. Ketika itu, batas tindak pidana ringan ialah 26 gulden. Setelah itu pada 1960, sistem hukum Indonesia mengadaptasi batas pencurian ringan menjadi harus diakui bahwa selama ini KUHP yang dipakai sebagai pedoman dan parameter untuk menentukan kriteria tindak pidana ringan sudah berusia lebih dari 60 tahun. Ketika itu, batas tindak pidana ringan ialah 26 gulden. Setelah itu pada 1960, sistem hukum Indonesia mengadaptasi batas tindak pidana ringan menjadi $\mathrm{Rp}$ 250,00 (dua ratus lima puluh rupiah), dengan perbandingan pada waktu itu harga minyak U\$ 1,8 per barel dan harga emas dunia U\$35 per ons. Jika dibandingkan dengan situasi saat ini, harga minyak dunia bekisar U\$100 per barel dan harga emas menembus hingga U\$ 1.700 per ons (Wibowo, 2016). Tidak disesuaikannya nilai mata uang dalam KUHP menyebabkan kasus-kasus seperti yang terjadi pada nenek Minah, yang diperlakukan seperti pencurian biasa (Pasal 362 KUHP) yang diancam dengan ancaman hukuman 5 tahun penjara. Selain itu hanya karena kasus pencurian 2 buah kakao, pencurian sendal jepit, pencurian 6 buah piring, atau kasus pencurian 2 buah semangka, yang nilainya tentu sudah tidak lagi dibawah Rp 250,00 (dua ratus lima puluh rupiah), para tersangka dan/atau terdakwanya dapat dikenakan penahanan oleh penyidik maupun penuntut umum.

Banyaknya perkara-perkara pencurian dengan nilai barang yang kecil yang kini diadili di pengadilan cukup mendapatkan sorotan masyarakat. Masyarakat umumnya menilai bahwa sangatlah tidak adil jika perkara-perkara tersebut diancam dengan ancaman hukuman 5 (lima) tahun sebagaimana diatur dalam Pasal 362 KUHP oleh karena tidak sebanding dengan nilai barang yang dicurinya (Penjelasan Umum Perma Nomor 2 Tahun 2012 tentang Penyesuaian Batasan Tindak Pidana Ringan dan Jumlah Denda Dalam KUHP). Jika dibandingkan dengan para pelaku tindak pidana berat misalnya koruptor, tentu hal ini menimbulkan reaksi yang membuat geram masyarakat. Hakim dalam mengadili suatu perkara sering dihadapkan pada suatu ketentuan bahwa kasus tersebut belum diatur dalam suatu peraturan, yang menyebabkan terhambatnya upaya mewujudkan penegakan hukum. Hal ini dikarenakan peraturan terdahulu tidak lengkap dan sudah ketinggalan dengan dinamika perubahan zaman. Mau tidak mau 
hakim harus mampu mengatasi problem tersebut dengan kewajiban mencari, menggali fakta, serta menemukan hukum sesuai nilai-nilai dan rasa keadilan yang hidup dalam masyarakat (Gultom, 2016:9).

Apabila ditafsirkan dapat memicu orang-orang untuk melakukan pencurian ringan beramai-ramai mengambil milik orang lain yang nilainya di bawah Rp2.500.000,00 (dua juta lima ratus ribu rupiah). Bagi remaja yang rentan berperilaku menyimpang akan dengan mudah melakukan tindak pidana ringan. PERMA ini dikhawatirkan dijadikan alat untuk berlindung bagi oknum-oknum yang tidak bertanggung jawab, serta menjadi alat tawar-menawar penegakan hukum dengan mengatur batas nominal nilai yang dicuri sehingga terbebas dari jeratan hukum. PERMA ini menimbulkan kesan terburuburu, seharusnya dilakukan pembahasan dengan pakar-pakar dan praktisi hukum sehingga ditemukan cara penanggulangan yang tepat dan efektif untuk menangani kasus-kasus tindak pidana ringan seperti pencurian.

Mahkamah Agung dalam mengeluarkan PERMA Nomor 2 Tahun 2012 hanya bersifat parsial tidak komprehensif dan holistik. Hal ini terjadi karena Mahkamah Agung keliru dalam penempatan nilai barang atau uang tidak lebih dari Rp2.500.000,00 (dua juta lima ratus ribu rupiah) sangatlah tidak mencerminkan nilai-nilai keadilan karena di setiap wilayah mempunyai tingkat pendapatan yang berbeda-beda, mungkin masyarakat dikota yang mempunyai pendapatan yang cukup besar sehingga nilai barang atau uang Rp2.500.000,00 (dua juta lima ratus ribu rupiah) tidaklah berarti dibandingkan dengan masyarakat desa yang mempunyai pendapatan rendah, nilai barang atau uang nilai uang Rp2.500.000,00 (dua juta lima ratus ribu rupiah) sangatlah berarti.

PERMA Nomor 2 Tahun 2012 juga menuai pro dan kontra. Tentu saja pro-kontra itu tidak terlepas dari sisi pandang yang dijadikan pijakan. Perdebatan atas PERMA Nomor 2 Tahun 2012 ini tampak mengarah pada latar belakang PERMA Nomor 2 Tahun 2012 sebagaimana dilansir sejumlah media yakni upaya pemberian rasa keadilan bagi masyarakat terutama dalam penyelesaian perkara-perkara tindak pidana ringan. Akan tetapi ada juga pandangan yang mengkuatirkan dengan adanya PERMA Nomor 2 Tahun 2012 akan menjamurnya kejahatankejahatan atau tindak pidana dengan nilai denda Rp2.500.000,00 (dua juta lima ratus ribu rupiah). Menurut wakil Direktur Pusat Studi Hukum dan Pembaharuan Nuriono mengatakan dilema dari pelaksaan PERMA Nomor 2 Tahun 2012 yaitu berupa tidak adanya spesifikasi tentang tindak pidana ringan yang diperbuat pelaku, padahal KUHP telah mengatur bahwa kejahatan bisa dijerat hukum penjara (Medan Bisnis, 2013).

PERMA Nomor 2 Tahun 2012 tersebut mengatur ketentuan tentang perubahan isi dari KUHP namun menurut Ronald S. Lumbun bahwa PERMA ini berperan diantara sebagai pengisi kekosongan hukum atau sebagai pelengkap ketentuan undang-undang khususnya yang berkaitan dengan hukum acara, sebagai sarana penemuan hukum dan sumber hukum bagi masyarakat selain itu PERMA ini merupakan produk atas hasil tindak lanjut dari hasil diskusi mengenai kebijakan-kebijakan tertentu yang dibahas dalam RAKERNAS V akan tetapi PERMA Nomor 2 Tahun 2012 ini tentu bertabrakan dengan Wewenang dari Mahkamah Agung itu sendiri karena tidak memiliki peran untuk mengubah undangundang (Lumbun, 2010: 14).

Dilihat dari sisi kedudukan hukum di Indonesia, PERMA Nomor 2 Tahun 2012 sangatlah tidak memungkinkan untuk merubah KUHP karena negara kita ini menganut asas lex superior derogate legi iferiori yang berarti bahwa peraturan perundangundangan yang secara hirarki lebih tinggi, akan mengesampingkan peraturan perundang-undangan yang hierarkinya lebih rendah hal terlihat dalam hirarki perundang-undangan seperti Pasal 7 dan Pasal 8 Undang-Undang Nomor 12 Tahun 2012 tentang Pembentukan Perundang-Undangan. 


\section{RUMUSAN MASALAH}

Berdasarkan uraian pada latar belakang penelitian, maka dikemukakan permasalahan dalam penelitian ini sebagai berikut:

1. Bagaimana kedudukan pidana denda memiliki kekuatan mengikat secara hukum sesuai PERMA Nomor 2 Tahun 2012 tentang Penyesuaian Batasan Tindak Pidana Ringan dan Jumlah Denda dalam KUHP dalam Perspektif Sistem Peradilan Pidana?

2. Bagaimanakah penerapan pidana denda menurut PERMA Nomor 2 Tahun 2012 tentang Penyesuaian Batasan Tindak Pidana Ringan dan Jumlah Denda dalam KUHP dalam menyelesaian kasus tipiring di Pengadilan Negeri Kelas I Kupang?

\section{METODE PENELITIAN}

Penelitian ini menggunakan metode penelitian normatif atau penelitian kepustakaan, atau dalam istilah Soetandyo Wignyosoebroto disebut dengan penelitian hukum doktrinal (Setiono, 2010 : 24). Yang dimaksud dengan penelitian hukum normatif menurut Peter Mahmud Marzuki adalah : "suatu proses untuk menemukan suatu aturan hukum, prinsip-prinsip hukum, maupun doktrin-doktrin hukum untuk menjawab permasalahan yang dihadapai. Penelitian hukum normatif dilakukan untuk menghasilkan argumentasi, teori atau konsep baru sebagai preskripsi dalam menyelesaikan masalah yang dihadapi”. (Peter Mahmud Marzuki, 2005 : 3). Semua bahan hukum primer, bahan hukum sekunder, dan bahan hukum tersier yang telah diolah dengan baik secara yuridis preskriftif, yaitu hasil kajian dengan merumuskan dan mengajukan pedoman-pedoman dan kaidah-kaidah yang harus dipatuhi oleh praktik hukum dan dogmatik hukum serta bersifat kritis.

\section{HASIL PENELITIAN DAN ANALISIS}

A. Kedudukan pidana denda sesuai ketentuan PERMA Nomor 2 Tahun 2012 tentang Penyesuaian Batasan Tindak Pidana Ringan Kedudukan denda dalam PERMA Nomor 2 Tahun 2012 tentang Penyesuaian Batasan Tindak Pidana Ringan dan Jumlah Denda dalam KUHP sangat penting untuk dibahas karena dapat mempengaruhi penanganan perkara tindak pidana dalam Sistem Peradilan Pidana di Indonesia. Sebagaimana telah dibahas sebelumnya bahwa PERMA pada dasarnya hanya mengikat para pihak yang bersengketa di pengadilan yaitu hakim, jaksa dan terdakwa serta penasehat hukumnya. Sedangkan dalam Sistem Peradilan Pidana, pihak yang terlibat didalamnya adalah Sub Sistem Kepolisian sebagai penyidik, sub sistem Kejaksaan sebagai Penuntut Umum, sub sistem Pengadilan sebagai hakim dan sub sistem pemasyarakatan. Melihat kekuatan mengikat peraturan Mahkamah Agung tersebut dalam suatu Sistem Peradilan Pidana, yang terikat oleh Peraturan tersebut hanyalah Sub Sistem Pengadilan yaitu hakim saja.

Sinkronisasi substansial merupakan sistem penegakan substansi hukum pidana yang meliputi hukum pidana materiel, hukum pidana formal, dan hukum pelaksanaan pidana disini harus ada keseragaman dan keselarasan yang bersifat vertikal maupun horizontal dalam kaitannya dengan hukum positif yang berlaku. Jika diperhatikan PERMA Nomor 2 Tahun 2012 ini merupakan suatu bentuk penyelarasan substansi hukum pidana pidana yang diatur dalam hukum pidana materiil (KUHP), hal ini terlihat pada Pasal 1 PERMA Nomor 2 Tahun 2012 yang menyelaraskan pengaturan jumlah nilai barang atau uang yang terdapat dalam pasal 364, 373, 379, 384, 407 dan 482 KUHP tidak melebihi dari Rp2.500.000,00 (dua juta lima ratus ribu rupiah) dikarenakan bahwa jumlah denda dalam KUHP sudah tidak relevan untuk diterapkan. Dan menurut Pasal 3 PERMA ini maksimum hukuman denda yang diancam dalam KUHP, kecuali pasal 303 ayat (1) 
dan (2) bisa dilipat gandakan 1000 (seribu) kali. Sedangkan dalam hukum pidana formal PERMA Nomor 2 Tahun 2012 ini sebagaimana diatur dalam Pasal 1 ayat 2 yang menyebutkan bahwa dalam menerima pelimpahan perkara pencurian, penipuan, penggelapan, penadahan dari penuntut umum maka ketua pengadilan wajib memperhatikan nilai barang, pengaturan dalam ayat 2 lebih lanjut menyatakan bahwa bila perbuatan tersebut termasuk dalam tindak pidana ringan, maka ketua pengadilan segera menetapkan hakim tunggal untuk memeriksa, mengadili dan memutus perkara tersebut dengan acara pemeriksaan cepat yang diatur dalam Pasal 205 sampai dengan Pasal 210 Kitab Undang-Undang Hukum Acara Perdata. Akan tetapi sampai dengan saat ini setelah dikeluarkannya PERMA tersebut masih terdapat perkara tindak pidana yang dikategorikan sebagai tindak pidana ringan tetapi dalam pemeriksaan yang dilakukan dengan pemeriksaan biasa hal ini yang dirasa kurang memberikan kepuasan kepada rakyat yang mengharapkan keadilan.

Berdasarkan PERMA Nomor 2 Tahun 2012 ini, nilai Rp250,00 (dua ratus lima puluh rupiah) disesuaikan dengan kondisi saat ini menjadi Rp2.500.000,00 (dua juta lima ratus rupiah). Oleh sebab itu, setiap perkara yang terkait dengan nilai barang tidak lebih dari Rp2.500.000,00 (dua juta lima ratus ribu rupiah) ditangani sebagai tindak pidana ringan dan diperiksa dengan acara cepat sebagaimana diatur dalam Pasal 205-210 Kitab Undang-Undang Hukum Acara Pidana. Akan tetapi, aparat kepolisian dan kejaksaan tidak memiliki kewajiban untuk mengikuti PERMA tersebut dan dalam menjalankan tugasnya masih mengacu atau berpedoman pada KUHP dan Kitab Undang-Undang Hukum Acara Pidana. Tentu hal ini menyebabkan ketidaklancaran pada sistem yang sedang berjalan. Ketidaklancaran tersebut bukan saja mempengaruhi efisiensi, efektivitas, dan produktifitas peradilan, melainkan ancaman kegagalan dalam menjalankan sistem peradilan yang baik. Seperti terhambatnya proses yang timbul karena bolak-baliknya berkas perkara antara penyidik dan penuntut umum serta penolakan dakwaan oleh hakim karena dianggap ada kekeliruan dalam merumuskan dakwaan, dan lain sebagainya (Hafrida, 2008).

Berdasarkan keterangan bapak Wisnu Wardana (Kasih Pidum Kejaksaan Negeri Kupang) mengatakan bahwa setelah PERMA Nomor 2 tahun 2012 ini dikeluarkan kejaksaan negeri Kupang tidak menggunakan PERMA tersebut dikarenakan adanya rasa ketidakadilan yang disampaikan oleh saksi korban kepadanya terkait dengan nilai barang tidak lebih dari Rp2.500.000,00 (dua juta lima ratus ribu rupiah) sangatlah berarti bagi saksi korban kemudian yang menjadi pertimbangan adalah ketika perkara pidana yang nilai barang tidak lebih dari Rp2.500.000,00 (dua juta lima ratus ribu rupiah). Dilimpahkan ke pengadilan dengan dengan acara pemeriksaan biasa dan yang berhak menilai perkara tersebut adalah hakim dan mengembalikan berkas perkara tersebut kepada jaksa penuntut umum untuk kemudian diperiksa dengan acara pemeriksaan cepat sebagaimana diterapkan untuk perkara tindak pidana ringan. Karena diperiksa dengan acara pemeriksaan cepat maka peran penuntut umum dikuasakan kepada penyidik untuk melanjutkan perkara tersebut langsung ke pengadilan. Hal ini tentunya sangat mempengaruhi sistem yang berjalan yang mana menurut Wisnu Wardana ketika berkas perkara tersebut dikembalikan oleh pengadilan untuk diterapkannya PERMA tersebut, akan tetapi Jaksa Penuntut Umum tidak dapat mengembalikan berkas perkara tersebut kepada penyidik dikarenakan pada tahap pelimpahan berkas perkara dari penyidik kepada Jaksa Penuntut Umum dan setelah berkas perkara tersebut diteliti oleh Jaksa penuntut umum dan dinyatakan bahwa berkas perkara tersebut sudah lengkap (P21) maka perkara tersebut bukan lagi menjadi tanggungjawab penyidik melainkan sudah menjadi tanggung jawab Jaksa Penuntut Umum. Apabila Jaksa Penuntut Umum menerapkan PERMA tersebut hal ini akan bertentangan dengan Pasal 205 
ayat (2) Kitab Undang-Undang Hukum Acara Pidana yang mana menurut pasal tersebut dalam hal perkara tindak pidana ringan penyidik bertindak sebagai penuntut umum, sehingga Jaksa Penuntut Umum tidak dapat bertindak sebagai penuntut umum dalam proses pemeriksaan dengan cara cepat. Hal tersebut akan berdampak pada proses penyelesaian perkara tersebut menjadi tidak jelas. Berdasarkan persoalan tersebut mempengaruhi efektifitas dan efisiensi sistem peradilan pidana karena terjadinya tumpang tindih atau ketidaklancaran dalam proses penangan perkara dalam sistem tersebut.

Hukum diciptakan agar setiap individu anggota masyarakat melakukan suatu tindakan yang diperlukan untuk menjaga ikatan sosial dan mencapai tujuan kehidupan bersama atau sebaliknya agar tidak melakukan suatu tindakan yang dapat merusak tatanan keadilan jika tindakan yang diperintahkan tidak dilakukan atau suatu larangan dilanggar. Tatanan sosial akan terganggu karena tercideranya keadilan, untuk mengembalikan tertib kehidupan bermasyarakat, keadilan harus ditegakkan setiap pelanggaran akan mendapatkan sanksi sesuai dengan tingkat pelanggaran itu sendiri.

PERMA Nomor 2 Tahun 2012 tentang Penyesuaian Tindak Pidana Ringan dan Jumlah Denda dalam KUHP merupakan itikad baik dari Mahkamah Agung untuk memperbaiki proses peradilan namun upaya memperbaiki proses peradilan tersebut berdasarkan kewenangan Mahkamah Agung hanya diterapkan atau hanya mengikat di lingkungan pengadilan yaitu hakim saja, PERMA ini tidak mampu secara hukum menjangkau pihak lain yang berada Sistem Peradilan pidana seperti penyidik maupun jaksa penuntut umum. Selain itu PERMA tersebut tidak memiliki batasanbatasan hukum misalnya klasifikasi tindak pidana ringan apa saja yang termasuk nominal dibawah Rp2.500.000,00 (dua juta lima ratus ribu rupiah), karasteristik tindak pidana ringan yang bagaimana persyaratannya, locus delikti, kondisi korban dan lain sebagainya. Hal ini akan berimbas pada proses penyidikan tindak pidana yang mana diketahui bersama bahwa awal mula diproses suatu perkara tindak pidana dimulai dari kepolisian dalam hal ini penyidik setelah itu Jaksa Penuntut Umum sehingga PERMA ini tidak menjamin adanya keadilan dan kepastian hukum hal ini juga dikarena PERMA tersebut bukan aturan yang bersifat umum.

\section{B. Penerapan pidana denda sesuai PERMA} Nomor 2 Tahun 2012 tentang Penyesuaian Batasan Tindak Pidana Ringan dan Jumlah Denda dalam KUHP Pada Pengadilan Negeri Kelas I Kupang

Definisi mengenai tindak pidana ringan tidak ditemukan di dalam KUHP, akan tetapi definisi tindak pidana ringan ditemukan dalam Kitab Undang-Undang Hukum Acara Pidana yang merupakan ketentuan hukum pidana formil. Pasal 205 ayat (1) Kitab Undang-Undang Hukum Acara Pidana yang mengatur mengenai ketentuan pemeriksaan acara cepat menyatakan bahwa:

"Yang diperiksa menurut acara pemeriksaan tindak pidana ringan ialah perkara yang diancam dengan pidana atau kurungan paling lama tiga bulan atau denda sebanyak- banyaknya tujuh ribu lima ratus rupiah dan penghinaan ringan kecuali yang ditentukan dalam paragraf 2 bagian ini”.

Kitab Undang-Undang Hukum Acara Pidana memberikan penjelasan dari bunyi pasal ini yaitu:

"Tindak Pidana "Penghinaan Ringan" ikut digolongkan disini dengan disebut sendiri, karena sifatnya ringan sekalipun ancamannya, pidana penjara paling lama empat bulan”.

Dari bunyi pasal tersebut dapat ditarik kesimpulan bahwa definisi tindak pidana ringan yaitu sebuah perkara yang ancaman hukuman penjara atau kurungan paling lama 3 (tiga) bulan dan atau denda paling banyak tujuh ribu lima ratus rupiah. Berdasarkan pasal tersebut perkara penghinaan ringan sekalipun diancam dengan hukuman yang lebih berat dari tiga bulan penjara namun masih dikateorikan sebagai tindak pidana ringan karena 
bersifat cukup ringan. Dalam KUHP terdapat Pasalpasal yang dikategorikan sebagai tindak pidana ringan yaitu pencurian ringan Pasal 364, penggelapan ringan Pasal 373, penipuan ringan Pasal 379, 384, pengrusakan Pasal 407, dan penadahan ringan Pasal 482 KUHP dan dengan secara jelas menyebutkan sebuah perkara bisa dikategorikan tindak pidana ringan jika menyangkut nilai uang dibawah 250 rupiah. Dengan nilai sekecil ini sesungguhnya KUHP tidak pernah membatasi kategori tindak pidana ringan yang dapat diproses di pengadilan dan mempergunakan mekanisme acara pemeriksaan biasa.

Mahkamah Agung Mengeluarkan PERMA Nomor 2 Tahun 2012 tentang Penyesuaian Batasan Tindak Pidana Ringan dan Jumlah Denda dalam KUHP, pada tanggal 27 Februari 2012. PERMA menentukan bahwa perkara-perkara sebagaimana tercantum dalam KUHP yaitu Pasal 364 KUHP (Pencurian Ringan), Pasal 373 KUHP (Penggelapan Ringan), Pasal 379 (Penipuan Ringan), Pasal 384 KUHP (Keuntungan dari Penipuan), Pasal 407 KUHP (Pengrusakan Ringan), dan Pasal 482 KUHP (Penadahan Ringan), yang nilainya dibawah Rp2.500.000,00 (dua juta lima ratus ribu rupiah) merupakan tindak pidana yang dikategorikan tindak pidana ringan oleh karena itu Ketua Pengadilan menetapkan hakim tunggal untuk memeriksa, mengadili dan memutuskan perkara tersebut dengan acara pemeriksaan cepat yang diatur dalam Pasal 205 KUHP, Ketua Pengadilan tidak menetapkan penahanan atau perpanjangan penahanan.

Penanganan perkara tersebut tentunya memiliki pengaruh terhadap sistem peradilan pidana karena penyesuaian nilai barang dalam Pasal 364, 373, 379, 384, 407 ayat (1) dan 482 KUHP diatur melalui sebuah PERMA yang memiliki kedudukan dan kekuatan yang mengikat ke dalam yaitu hanya mengikat pengadilan saja sedangkan penyidik dan penuntut umum tidak mempunyai kewajiban untuk menggunakan atau menerapkan PERMA tersebut.
PERMA Nomor 2 Tahun 2012 ini memunculkan beragam reaksi pro-kontra dari berbagai kalangan. Pada satu sisi, ada yang mempermasalahkan bahwa penyesuaian batasan tindak pidana ringan dan jumlah KUHP pada sebuah peraturan yang di keluarkan oleh Mahkamah Agung merupakan suatu kecacatan hukum. Dan ada pula yang beranggapan bahwa Mahkamah Agung dalam menerbitkan PERMA Nomor 2 Tahun 2012 sangat terburu-buru mengingat substansi peraturan tersebut yang dianggap kurang tepat untuk diberlakukan karena nominal nilai barang atau uang Rp2.500.000,00 (dua juta lima ratus ribu rupiah) tidak dapat dijadikan sebagai satu-satunya patokan untuk menentukan suatu tindak pidana dikategorikan sebagai tindak pidana ringan.

Hasil penelitian penulis di Pengadilan Negeri Kelas I Kupang berkaitan dengan penerapan PERMA Nomor 2 Tahun 2012 tentang Penyesuaian batasan tindak pidana ringan dan denda dalam KUHP, Perkara Nomor 205/Pen.Pid/2015/PN.KPG adalah perkara tindak pidana Pencurian dengan terdakwa yang bernama Yohamir Amtiran alias Hamir Amtiran melakukan tindak pidana pencurian barang berupa 1 buah jam tangan merk Giotana berwarna silver berbentuk kotak, 1 buah jam tangan merk Seiko berbentuk bulat berwarna emas pada malam hari disebuah rumah yang tertutup milik saksi korban yang bernama Indriani Listya Purwanti alias Indri di perumahan BSB Jl. Puri Lontar, Kelurahan Oebufu Kecamatan Oebobo, Kota Kupang. Nilai kerugian yang dialami korban kurang lebih sebesar Rp1.500.000,00 (satu juta lima ratus ribu rupiah). Terdakwa diadili dengan acara pemeriksaan biasa dan dilakukan penahanan.

Pengadilan Negeri Kupang tidak dapat menerapkan PERMA Nomor 2 Tahun 2012 karena beberapa hal yang pertama bahwa didalam menilai suatu perkara tindak pidana bukan saja berpatokan pada nilai barang atau uang yang menjadi objek perkara akan tetapi dinilai dari cara terdakwa melakukan tindak pidana tersebut, juga waktu dan 
tempat dimana terdakwa melakukan tindak pidana tersebut serta unsur-unsur pasal yang didakwakan Jaksa Penuntut Umum. Kedua nilai barang atau uang menurut PERMA Nomor 2 Tahun 2012 tidak lebih dari Rp2.500.000,00 (dua juta lima ratus ribu rupiah) maka Ketua Pengadilan segera menetapkan hakim tunggal untuk memeriksa dan mengadili dan memutuskan perkara tersebut dengan acara pemeriksaan cepat yang diatur dalam Pasal 205-210 Kitab Undang-Undang Hukum Acara Pidana, selanjutnya menurut Bapak Herbet Pengadilan Negeri Kelas I Kupang tidak dapat menerapkannya karena tingkat penghasilan setiap daerah berbedabeda. Nilai barang atau uang Rp2.500.000,00 (dua juta lima ratus ribu rupiah) tersebut mungkin di kota besar seperti Jakarta tidaklah berarti akan tetapi bagi masyarakat kota Kupang nilai barang atau uang Rp2.500.000,00 (dua juta lima ratus ribu rupiah) memiliki nilai yang besar. Ke-3 yang paling penting menurut Bapak Herbet yaitu kedudukan hukum dari PERMA Nomor 2 Tahun 2012 tersebut tidak termasuk dalam hirarki peraturan perundangundangan dan selama ini Pengadilan Negeri Kelas I Kupang masih berpedoman pada KUHP dan Kitab Undang-Undang Hukum Acara Pidana serta yang ke4 bahwa sampai dengan saat ini belum ada perkara tindak pidana yang dilimpahkan oleh Jaksa Penuntut Umum yang menggunakan PERMA Nomor 2 Tahun 2012 tersebut.

Hal ini sudah ditegaskan Bapak Wisnu Wardana sebagai Kasih Pidum pada Kejaksaan Negeri Kupang bahwa Kejaksaan Negeri Kupang tidak dapat menerapkan PERMA ini dikarenakan PERMA merupakan peraturan (regiling) yang mengikat hanya untuk hakim-hakim di lingkungan Mahkamah Agung sehingga kejaksaan dan penyidik kepolisian tidak berkewajiban untuk menerapkan PERMA tersebut. Selain itu nilai barang atau uang yang menjadi objek perkara menurut Mahkamah Agung Nomor 2 Tahun 2012 tersebut harus dibawah Rp2.500.000,00 (dua juta lima ratus ribu rupiah) hal ini bertentangan dengan rasa keadilan yang diterima oleh korban atas perbuatan yang dialaminya disini rasa itu tidak diakomodir PERMA tersebut karena nilai barang atau uang Rp2.500.000,00 (dua juta lima ratus ribu rupiah) bagi masyarakat kota Kupang sangat besar dan sangat berarti dibandingkan dengan daerah metropolitan lainnya seperti di Jakarta yang tidak ada artinya. Sehingga setelah PERMA ini diterbitkan Kejaksaan Negeri Kupang tidak pernah melimpahkan perkara pidana yang dikategorikan ringan ke Pengadilan Negeri Kelas I kupang.

Menurut PERMA Nomor 2 Tahun 2012 tentang Penyesuaian Batasan Tindak Pidana Ringan dan jumlah denda dalam KUHP, pada Pasal 2:

Ayat (1) Dalam menerima pelimpahan perkara pencurian, penipuan, penggelapan penadahan dari penuntut umum, ketua pengadilan wajib memperhatikan nilai barang atau uang yang menjadi objek perkara dan memperhatikan Pasal 1 ayat (2) Apabila nilai barang atau uang tersebut bernilai tidak lebih dari Rp2.500.000,00 (dua juta lima ratus ribu rupiah) Ketua Pengadilan segera menetapkan hakim tunggal untuk memeriksa, mengadili dan memutus perkara tersebut dengan Acara Pemeriksaan cepat yang diatur dalam Pasal 205-210 Kitab Undang-Undang Hukum Acara Pidana ayat (3) Apabila terdakwa ditahan sebelumnya dikenakan penahanan, Ketua Pengadilan tidak menetapkan penahanan ataupun perpanjangan penahanan.

Hal ini bertentangan dengan aturan dalam hukum acara pidana yang mana menurut Pasal 205210 Kitab Undang-Undang Hukum Acara Pidana tentang acara pemeriksaan cepat yang telah dibahas sebelumnya bahwa perkara tindak pidana ringan sebagaimana dijelaskan pada Pasal 205 ayat (2) yaitu:

"Penyidik atas kuasa penuntut umum dalam waktu tiga hari sejak berita acara pemeriksaan selesai dibuat menghadapkan terdakwa, beserta barang bukti, saksi ahli dan juru bahasa kesidang pengadilan hal ini menjelaskan bahwa pelimpahan perkara tindak pidana ringan dilakukan oleh penyidik atas kuasa penuntut umum”. 
Berdasarkan penjelasan Pasal 205 ayat (2) tersebut maka "atas kuasa" penuntut umum tersebut merupakan "demi hukum" ditentukan secara tegas oleh undang-undang dan secara otomatis menjadi "atas kuasa undang-undang" oleh sebab itu, penyidik bertindak "atas kuasa” penuntut umum tanpa perlu didahului adanya surat kuasa karena undang-undang telah mengatur hal tersebut.

\section{SIMPULAN DAN SARAN}

A. Simpulan

1. Kedudukan pidana denda dalam PERMA Republik Indonesia Nomor 2 Tahun 2012 tentang Penyesuaian Batasan Tindak Pidana Ringan dan Jumlah Denda dalam KUHP belum menjamin ditegakannya untuk memenuhi rasa keadilan dalam hukum, sebab sekalipun dituntut dan diputuskan pengadilan namun sifatnya belum memberikan kewajiban bagi aparatur penegak hukum untuk menerapkannya.

2. Di Kantor Pengadilan Negeri Kelas 1A Kupang, penerapan Peraturan pidana denda menurut PERMA Nomor 2 Tahun 2012 tentang Penyesuaian Batasan Tindak Pidana Ringan dan Jumlah Denda dalam KUHP sekalipun sudah ada takaran atau ukurannya namun belum seimbang dengan nilai jual barang dan jasa ada. Hal ini dipandang perlu untuk patut dikatahuinya sebab ketentuan pidana denda hanya merupakan pidana tambahan. Memang antara jaksa dan hakim belum menerapkannya untuk memenuhi rasa keadilan masyarakat. Penyelesaian kasus yang dikategorikan sebagai tindak pidana ringan dalam menilai suatu perkara tindak pidana tidak saja dinilai dari nilai barang atau uang yang menjadi objek perkara melainkan bagaimana caranya terdakwa dalam melakukan tindak pidana tersebut.

\section{B. Saran}

1. Agar pidana denda menjadi sempurna untuk memenuhi rasa keadilan yang ada dalam masyarakat, maka sebaiknya selain ditetapkannya PERMA Nomor 2 Tahun 2012, untuk menjadi rujukan bagi para hakim dan atau aparat penegak hukum tentu pemerintah dan DPR harus segera membahas dan menetapkan Rancangan Undang-Undang KUHP supaya bisa mengendalikan keresahan yang dihadapi oleh masyarakat akibat pidana denda yang tidak bisa menyelesaikan masalah pidana yang dilakukan oleh pelaku. Sekalipun tindak pidana ringan perlu ada instrumen untuk bisa menuntut para hakim dan jaksa dalam menerapkan hukum demi menjaga ketertiban dan keamanan dalam masyarakat;

2. Subtansi PERMA Nomor 2 Tahun 2012 ini perlu direvisi kembali dengan memperhatikan hal-hal sebagai berikut khusus pada pasal yang dipersangkakan harus mempunyai unsur-unsur yang jelas, tingkat kemiskinan di suatu wilayah, pendapatan perkapita masyarakat di kota dan di desa dan melakukan koordinasi dengan kepolisian dan kejaksaan sehubungan dengan penahanan dan besarnya jumlah denda sehingga penegakan hukum dapat berjalan dengan baik dan diterapkan secara tepat dan benar serta memenuhi rasa keadilan bagi masyarakat.

\section{DAFTAR PUSTAKA}

Buku

Binsar, Gultom, 2012, Pandangan Kritis Seorang Hakim dalam Penegakan Hukum di Indonesia, Jakarta, PT. Gramedia Pustaka Utama.

Lumbun, Ronal S., 2010, Wujud Kerancuan antara Praktek Pembagian dan Pemisahan Kekuasaan, Jakarta, Rajawali Press.

Marzuki, Peter Mahmud, 2005, Penelitian Hukum, Jakarta, Kencana.

Setiono, 2010, Pemahaman terhadap Metodologi Penelitian Hukum, Surakarta, Program Studi Ilmu Hukum Pascasarjana Universitas Sebelas Maret. 
Soekanto, Soerjono dan Sri Mamudji, 2012, Penelitian Hukum Normatif, Suatu Tinjauan Singkat, Jakarta, RajaGrafindo.

\section{Jurnal}

Hafrida, 2008, "Sinskronisasi Antar Lembaga Penegak Hukum dalam Mewujudkan Sistem Peradilan Pidana Terpadu", Majalah Hukum Forum Akademika, Vol 18, Nomor 2.

\section{Website}

Jamal Wiwoho, "Penegakan Hukum atas Pencurian Ringan”, http://jamalwiwoho.com/category/ opini, Media Indonesia e-paper h.26, diakses tanggal 12 Desember 2016

Medan Bisnis, 2013, "Perma No. 2 tahun 2012 Berpotensi Disalah Gunakan”, http://www.medanbisnisdaily.com/, Tanggal 13 Maret 2015, diakses, 15 September 2016

\section{Peraturan Perundang-Undangan}

Undang-undang Dasar Negara Republik Indonesia Tahun 1945.

Undang-undang Nomor 1 Tahun 1946 tentang Kitab Undang-Undang Hukum Pidana.

Undang-undang Nomor 14 Tahun 1970 sebagaimana telah diubah dengan Undangundang Nomor 4 Tahun 2004 dan terakhir dengan Undang-undang Nomor 48 Tahun 2009 tentang Kekuasaan Kehakiman.

Undang-undang Nomor 8 Tahun 1981 Tentang Kitab Undang-undang Hukum Acara Pidana.

Undang-undang Nomor 14 Tahun 1985 tentang Mahkamah Agung RI sebagaimana telah diubah dan ditambah dengan Undang-undang Nomor 5 Tahun 2004 dan terakhir diubah dengan Undang-undang Nomor 3 Tahun 2009.

Undang-undang Nomor 8 Tahun 2004 Tentang Perubahan Undang-undang Nomor 2 Tahun 1986 Tentang Peradilan Umum.

Undang-undang Nomor 10 Tahun 2004 sebagaimana telah diubah dengan Undang-undang Nomor 12
Tahun 2011 tentang Pembentukan Peraturan Perundang-undangan.

Peraturan Pemerintah Pengganti Undang-undang Nomor 18 Tahun 1960 tentang Perubahan Jumlah Hukuman Denda dalam KUHP dan dalam Ketentuan Pidana Lainnya Yang Dikeluarkan Sebelum Tanggal 17 Agustus 1945.

Peraturan Mahkamah Agung RI Nomor 2 Tahun 2012 tentang Penyesuaian Batasan Tindak Pidana Ringan dan Jumlah Denda dalam KUHP. 